\title{
Quantitative Genetic Analysis for Yield and Yield Components in Boro Rice (Oryza sativa L.)
}

\author{
Supriyo CHAKRABORTY, Pradip K. DAS, Biswajit GUHA, \\ Kalyan K. SARMAH, Bhubaneswar BARMAN \\ Assam University,_Dept of Biotechnology, Silchar 788 011, Assam, India; supriyoch_2008@rediffmail.com (corresponding author)
}

\begin{abstract}
Twenty-nine genotypes of boro rice (Oryza sativa L.) were grown in a randomized block design with three replications in plots of $4 \mathrm{~m}$ x $1 \mathrm{~m}$ with a crop geometry of $20 \mathrm{~cm}$ x $20 \mathrm{~cm}$ between November-April, in Regional Agricultural Research Station, Nagaon, India. Quantitative data were collected on five randomly selected plants of each genotype per replication for yield/plant, and six other yield components, namely plant height, panicles/plant, panicle length, effective grains/panicle, 100 grain weight and harvest index. Mean values of the characters for each genotype were used for analysis of variance and covariance to obtain information on genotypic and phenotypic correlation along with coheritability between two characters. Path analyses were carried out to estimate the direct and indirect effects of boro rice's yield components. The objective of the study was to identify the characters that mostly influence the yield for increasing boro rice productivity through breeding program. Correlation analysis revealed significant positive genotypic correlation of yield/plant with plant height (0.21), panicles/plant (0.53), panicle length (0.53), effective grains/panicle (0.57) and harvest index (0.86). Path analysis based on genotypic correlation coefficients elucidated high positive direct effect of harvest index (0.8631), panicle length (0.2560) and 100 grain weight $(0.1632)$ on yield/plant with a residual effect of 0.33 . Plant height and panicles/plant recorded high positive indirect effect on yield/plant via harvest index whereas effective grains/panicle on yield/plant via harvest index and panicle length. Results of the present study suggested that five component characters, namely harvest index, effective grains/plant, panicle length, panicles/plant and plant height influenced the yield of boro rice. A genotype with higher magnitude of these component characters could be either selected from the existing genotypes or evolved by breeding program for genetic improvement of yield in boro rice.
\end{abstract}

Keywords: boro rice, correlation, path analysis, yield, components

\section{Introduction}

Boro rice (Oryza sativa L.) is widely grown during winter (November-April) in the flood prone areas in Assam. Heavy rainfall in the rainy season (June-September) causes flood every year in the low lying rice growing areas and makes rice cultivation a nightmare to the resource poor farmers. The farmers of this region prefer to grow boro rice in winter with assured irrigation for better yield. But the average productivity of boro rice ( $\mathrm{Ca} 1.5 \mathrm{t} / \mathrm{ha}$ ) in Assam is much lower than its potential (Ca $7 \mathrm{t} / \mathrm{ha}$ ). This calls for urgent attention of the rice breeders to develop high yielding genotypes of boro rice catering to such conditions. The development of a high yielding genotype through breeding rice, an autogamic species, requires a thorough knowledge of the association of the yield components (Kishor et al., 2008). Grain yield in rice is a complex character, quantitative in nature and an integrated function of a number of component traits (Sharma and Sharma, 2007). Therefore, selection for yield per se may not be much rewarding unless yield components are taken into consideration. Correlation analysis provides a good measure of the association between characters and helps to identify the most important character(s) to be considered for effective selection for increasing yield. The extent of direct and indirect effects of component characters on yield, elucidated through path coefficient analysis using correlations, helps further to choose the right characters as selection criteria. Such information referring to the genetic resources of boro rice of Assam is scanty. Therefore, the present study was undertaken with an objective to elucidate the basic genetic information on genetic correlation, coheritability and path coefficients of yield components on grain yield in boro rice.

\section{Materials and methods}

Twenty nine boro rice genotypes (Tab. 1) were grown in a randomized block design with three replications at Regional Agricultural Research Station, Nagaon, Assam during November-April. Each genotype was transplanted in lines in a small plot of size $4 \mathrm{~m} \times 1 \mathrm{~m}$ per replication with crop geometry of $20 \mathrm{~cm} \times 20 \mathrm{~cm}$ and recommended agronomic practice. Data were collected from five ran- 
118

domly selected plants of each genotype per replication for yield/plant (g) and six yield components [viz. plant height $(\mathrm{cm})$, panicles/plant, panicle length $(\mathrm{cm})$, effective grains/ panicle, 100 grain weight $(\mathrm{g})$ and harvest index].

Mean values of the characters for each genotype per replication were used for analysis of variance and covariance as per Singh and Chaudhary (1985). Genotypic and phenotypic correlation coefficients between any two characters were estimated according to Panse and Sukhatme (1957); coheritability between two characters as per Nei (1960). Direct and indirect effects through path analysis were estimated as per the procedure outlined by Dewey

Tab. 1. Name of the boro rice genotypes included in the experiment

\begin{tabular}{cccc}
\hline Sl. No. & Genotype & Sl. No. & Genotype \\
\hline 1 & 'Boro-1' & 16 & 'TR-118' \\
2 & 'Boro-2' & 17 & 'TRB-10' \\
3 & 'Tepi' & 18 & 'TRB-12' \\
4 & 'Sonari' & 19 & 'TRB-9' \\
5 & 'Gazi' & 20 & 'TRB-7' \\
6 & 'Mugsali-1' & 21 & 'TRB-15-1' \\
7 & 'Mugsali-2' & 22 & 'TRB-14-1' \\
\hline 8 & 'Sunamukhi' & 23 & 'TTB-1' \\
9 & 'Madhab boro' & 24 & 'TTB-10' \\
10 & 'China-5' & 25 & 'IET-8021' \\
11 & 'Pusa-5' & 26 & 'IET-9188' \\
12 & 'IR-50' & 27 & 'IET-9095' \\
13 & 'Joymati' & 28 & 'IET-9981' \\
14 & 'Bishnu' & 29 & 'Krishna' \\
15 & 'NDR-1001' & \\
\hline
\end{tabular}

and $\mathrm{Lu}$ (1959). Variances and correlation coefficients were tested for significance by " $\mathrm{F}$ " and " $\mathrm{t}$ " tests, respectively.

\section{Results and discussion}

The analysis of variance for each character revealed that the boro rice genotypes in the present study differed amongst themselves at $\mathrm{p}=0.01$. This indicated the presence of ample genetic variation among the genotypes for each quantitative character.

\section{Correlation}

The estimates of genotypic and phenotypic correlation coefficients along with coheritability among all the seven quantitative characters are presented in Tab. 2. In general the estimates of genotypic correlation were higher in magnitude than those of phenotypic correlation indicating strong inherent association between each pair of characters. The trend of correlation was identical at both genotypic and phenotypic planes indicated by the same sign in almost all the character pairs revealed identical direction of correlation at both the planes. It would certainly increase the efficiency of phenotypic selection.

In this study, yield/plant showed significant positive genotypic correlation with plant height (0.21), panicles/ plant (0.27), panicle length (0.53), effective grains/panicle $(0.57)$ and harvest index $(0.86)$ but significant negative correlation with 100 seed weight $(-0.35)$. Phenotypic correlations between seed yield/plant and other characters showed similar trend like genotypic correlations. Harvest index exhibited significant positive genotypic correlation with plant height $(0.30)$, panicles/plant $(0.43)$, panicle length (0.30) and effective grains/panicle (0.53) in addition to seed yield/plant. Effective grains/panicle revealed significant positive genotypic correlation with plant height (0.32), panicle length (0.89) and 100 grain weight $(0.35)$ in addition to yield/plant. Like the present study, yield/plant was reported to be positively correlated with plant height and panicles/plant by Singh et al. (1979); with panicle length by Sarma and Dwivedi (1980); with grains/panicle and 100 grain weight by Sharma and Sharma (2007). But negative genotypic correlation of yield/ plant was reported with panicle length by Saini and Gagneja (1975); with harvest index by Kishor et al. (2008). Positive correlation of harvest index with panicles/plant, panicle length, grains/panicle and 100 grain weight was observed by Ganesan et al. (1998).

\section{Coheritability}

Coheritability measures the possibility of the joint transmission of two characters and permits the study of simultaneous changes in two correlated characters through selection on one character. For effective selection, coheritability is usually studied with genotypic correlation in the absence of G-E interaction but with phenotypic correlation in presence of G-E effect. Coheritability estimates of different character pairs based on linkage are evanescent and reverse sign with crossing over. Such coheritability estimates are usually low unless linkage between character pairs is strong. In the present study, yield/plant showed high positive coheritability with harvest index (0.57), effective grains/panicle (0.36) and panicle length (0.35). Large magnitude of coheritability estimate in a character pair could be due to low environmental effect.

\section{Path analysis}

Yield is a complex resultant character and influenced by several components and environment. Due to internal adjustments among the components, increase in one component results in a decrease in other component $(s)$ and hence does not affect the resultant like yield. Path analysis is very useful in such complex situation to analyze the direct effect of each character and the indirect effects via other characters on yield.

Path analysis carried out on the basis of genotypic correlations revealed that harvest index, panicle length and 100 grain weight had shown high positive direct effect 
Tab. 2. Estimates of genotypic $\left(r_{\mathrm{g}}\right)$ and phenotypic $\left(r_{\mathrm{p}}\right)$ correlation coefficients and coheritability (coh) among different characters in boro rice

\begin{tabular}{|c|c|c|c|c|c|c|c|}
\hline Characters & $\begin{array}{c}\text { Correlation and } \\
\text { coheritability }\end{array}$ & $\begin{array}{c}\text { Panicles/ } \\
\text { plant }\end{array}$ & $\begin{array}{c}\text { Panicle } \\
\text { length }(\mathrm{cm})\end{array}$ & $\begin{array}{c}\text { Effective grains/ } \\
\text { panicle }\end{array}$ & $\begin{array}{l}100 \text { grain } \\
\text { weight }(\mathrm{g})\end{array}$ & $\begin{array}{c}\text { Harvest } \\
\text { index }\end{array}$ & $\begin{array}{l}\text { Yield/ } \\
\text { plant }\end{array}$ \\
\hline \multirow{3}{*}{ Plant height $(\mathrm{cm})$} & $r_{g}$ & $0.23^{*}$ & 0.10 & $0.32^{* *}$ & $-0.98^{* *}$ & $0.30^{* *}$ & $0.21^{*}$ \\
\hline & $r_{p}$ & 0.20 & 0.03 & $0.22^{*}$ & $0.48^{* *}$ & $0.22^{*}$ & 0.19 \\
\hline & coh & 0.18 & 0.07 & 0.22 & -0.54 & 0.02 & 0.18 \\
\hline \multirow{3}{*}{ Panicles/plant } & $r_{g}$ & & $-0.32^{* *}$ & 0.02 & $-0.62^{* *}$ & $0.43^{* *}$ & $0.27^{* *}$ \\
\hline & $r_{p}$ & & -0.12 & 0.05 & $-0.23^{*}$ & $0.28^{* *}$ & $0.23^{*}$ \\
\hline & coh & & -0.19 & 0.01 & -0.29 & 0.24 & 0.19 \\
\hline \multirow{3}{*}{$\begin{array}{l}\text { Panicle length } \\
\qquad(\mathrm{cm})\end{array}$} & $r_{g}$ & & & $0.89^{* *}$ & $0.57^{* *}$ & $0.30^{* *}$ & $0.53^{* *}$ \\
\hline & $r_{p}$ & & & $0.68^{* *}$ & $0.25^{* *}$ & 0.18 & $0.35^{* *}$ \\
\hline & coh & & & 0.48 & 0.24 & 0.17 & 0.35 \\
\hline \multirow{3}{*}{$\begin{array}{c}\text { Effective grains/ } \\
\text { panicle }\end{array}$} & $\mathrm{r}_{\mathrm{g}}$ & & & & $0.35^{* *}$ & $0.53^{* *}$ & $0.57^{* *}$ \\
\hline & $r_{p}^{g}$ & & & & 0.17 & $0.27^{*}$ & $0.40^{* *}$ \\
\hline & coh & & & & 0.14 & 0.27 & 0.36 \\
\hline \multirow{3}{*}{$\begin{array}{l}100 \text { grain weight } \\
(\mathrm{g})\end{array}$} & $r_{g}$ & & & & & $-0.58^{* *}$ & $-0.35^{* *}$ \\
\hline & $\mathrm{r}_{\mathrm{p}}$ & & & & & -0.17 & -0.12 \\
\hline & coh & & & & & -0.24 & -0.18 \\
\hline \multirow{3}{*}{ Harvest index } & $r_{g}$ & & & & & & $0.86^{* *}$ \\
\hline & $\mathrm{r}_{\mathrm{p}}^{\mathrm{s}}$ & & & & & & $0.69^{* *}$ \\
\hline & coh & & & & & & 0.57 \\
\hline
\end{tabular}

${ }^{*}, * *-$ - Significant at $5 \%$ and $1 \%$ levels, respectively

with a magnitude of $0.8631,0.2560$ and 0.1632 respectively on yield/plant. Similar results of harvest index on yield/plant were reported by Ganesan et al. (1998) and Chaturvedi et al. (2008); of panicle length on yield/plant by Kishor et al. (2008); of grain weight on yield/plant by length, panicles/plant and plant height influenced yield in boro rice either directly or indirectly. Thus a genotype with higher magnitude of these traits could be either selected from existing genotypes or evolved by breeding program for genetic improvement of yield in boro rice.

Tab. 3. Direct (diagonal values) and indirect effects of different characters on yield/plant at genotypic level

\begin{tabular}{cccccccc}
\hline Characters & Plant height & $\begin{array}{c}\text { Panicles/ } \\
\text { Plant }\end{array}$ & Panicle length & $\begin{array}{c}\text { Effective Grains/ } \\
\text { Panicle }\end{array}$ & $\begin{array}{c}\text { 100 grain } \\
\text { weight }\end{array}$ & $\begin{array}{c}\text { Harvest } \\
\text { index }\end{array}$ & $\begin{array}{c}\text { Genotypic correlation } \\
\text { with yield/ plant }\end{array}$ \\
\hline Plant height $(\mathrm{cm})$ & 0.0956 & 0.0141 & 0.0256 & -0.0245 & -0.1599 & 0.2589 & 0.21 \\
Panicles/plant & 0.0220 & 0.0615 & -0.0819 & -0.0015 & -0.1012 & 0.3711 & 0.27 \\
Panicle length $(\mathrm{cm})$ & 0.0096 & -0.0197 & 0.2560 & -0.0678 & 0.0930 & 0.2589 & 0.53 \\
Effective grains/panicle & 0.0306 & 0.0012 & 0.2279 & -0.0762 & 0.0571 & 0.3294 & 0.57 \\
\hline 100 grain weight $(\mathrm{g})$ & -0.0937 & -0.0937 & 0.1459 & -0.0267 & 0.1632 & -0.5006 & -0.35 \\
Harvest index & 0.0287 & 0.0264 & 0.0768 & -0.0404 & -0.0946 & 0.8631 & 0.86 \\
\hline
\end{tabular}

Chaturvedi et al. (2008) and Luzi Kihupi (1998).

Plant height and panicles/plant resulted high positive indirect effect on yield/plant via harvest index. Effective grains/panicle showed high positive indirect effect on yield/plant via harvest index and panicle length. The value of residual effect was 0.33 indicating that nearly $67 \%$ of genetic variability in yield could be accounted for by the components.

\section{Conclusions}

The results of the present study suggested that the characters viz. harvest index, effective grains/panicle, panicle

\section{Acknowledgements}

The authors are thankful to Assam Agricultural University, Jorhat, Assam, India, for providing the fund and the facilities to undertake the present study.

\section{References}

Chaturvedi, S., P. Lal, M. P. Pandey, S. Verma and A. P. Singh (2008). Component analysis for grain yield in hybrid rice under 'tarai' condition. Oryza. 45(1):1-6.

Dewey, D. R. and K. H. Lu (1959). A correlation and path coefficient analysis of components of crested wheat grass seed production. Agronomy Journal. 51:515-518. 
120

Ganesan, K., M. Subramaniam, M. W. Wilfred and T. Sundaram (1998). Correlation and path coefficient analysis of yield components in $\mathrm{F}_{2}$ and $\mathrm{F}_{3}$ generations of tall $\mathrm{x}$ dwarf rice cross. Oryza. 35(4):329-332.

Kishor, C., Y. Prasad, Z. A. Haider, R. Kumar and K. Kumar (2008). Quantitative analysis of upland rice. Oryza. 45(4): 268-274.

Luzi Kihupi, A (1998). Interrelationship between yield and some selected agronomic characters in rice. African Journal of Crop Science. 6(3):323-328.

Nei, M. (1960). Studies on the application of biometrical genetics to plant breeding. Mum. College Agriculture, Kyoto University, Japan. 82-100.

Panse, V. G. and P. V. Sukhatme (1978). Statistical Methods for Agricultural Workers. ICAR, New Delhi.

Saini, S. S. and M. R. Gagneja (1975). Interrelationship between yield and some agronomic characters in short statured rice cultivers. Indian Journal of Genetics and Plant Breeding. $35: 441-445$.
Sharma, N. K. and J. L. Dwivedi (1980). Significance of path coefficient analysis in determining the nature of character association in rice. Journal of Agricultural Science Society. Assam. 1:12-17.

Sharma, A. K. and R. N. Sharma (2007). Genetic variability and character association in early maturing rice. Oryza. 44(4): 300-303.

Singh, R. K. and B. D. Chaudhary (1985). Biometrical Methods in Quantitative Genetic Analysis. Kalyani publishers, Ludhiana, India.

Singh, V. P., M. S. Swaminathan, R. B. Mehra and E. A. Siddiq (1979). Divergence among dwarfs of cultivated rice. Indian Journal of Genetics and Plant Breeding. 39:315-322. 